ENTREPRENEURSHIP AND SUSTAINABILITY ISSUES

ISSN 2345-0282 (online) http://jssidoi.org/jesi/ 2021 Volume 9 Number 1 (September) http://doi.org/10.9770/jesi.2021.9.1(6)

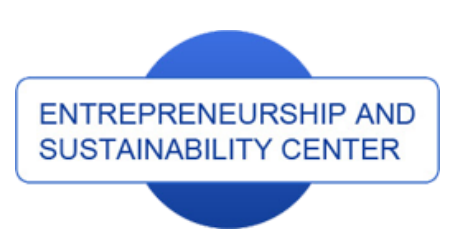

Publisher

http://jssidoi.org/esc/home enterprise

europe

network

Business Support on Your Doorstep

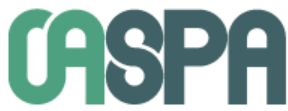

\title{
THE IMPACT OF EMPLOYEES' JOB STRESS AND CAREER SATISFACTION OVER CORPORATE ENTREPRENEURSHIP MANAGEMENT LINKED TO SOCIAL RESPONSIBILITY
}

\author{
Manuela Escobar-Sierra ${ }^{1 *}$, Felipe Calderón-Valencia ${ }^{2}$ \\ ${ }^{1,2}$ School of Administrative and Economic Sciences, University of Medellin, Carrera $87 N^{\circ}$ 30-6, Medellin Colombia \\ E-mails: $:^{*}$ manuelaescobar@gmail.com (Correponding author); ${ }^{2}$ felipecalderonvalencia@ gmail.com
}

Received 19 September 2020; accepted 25 Mayl 2021; published 30 September 2021

\begin{abstract}
The purpose of the present study is to analyze how employees' job stress and career satisfaction impact corporate entrepreneurship management linked to social responsibility in a Colombian Information Technology company. For that purpose, we review the evolution of the corporate entrepreneurship concept, as part of innovation models and as an explicit research term, in a specific context, where organizations need to take into account stakeholders' needs. Once completed the review, we present the research methodology with a quantitative approach, where we triangulate or compare the results of an artificial neural network and classification tree, for the job stress and career satisfaction surveys' of 110 employees. The results finally suggest that only the job stress impact the corporate entrepreneurship management linked to social responsibility. At the same time, career satisfaction does not seem to have significant effects over it, in the IT Company.
\end{abstract}

Keywords: employees; corporate entrepreneurship; innovation; job stress; career satisfaction; social responsibility; machine learning methods; quantitative approach; classification tree; artificial neural network

Reference to this paper should be made as follows: Escobar-Sierra, M., Calderón-Valencia, F. 2021. The impact of employees' job stress and career satisfaction over corporate entrepreneurship management linked to social responsibility. Entrepreneurship and Sustainability Issues, 9(1), 87-102. http://doi.org/10.9770/jesi.2021.9.1(6)

JEL Classifications: M1, M12, O31, O32 


\section{ENTREPRENEURSHIP AND SUSTAINABILITY ISSUES}

ISSN 2345-0282 (online) http://jssidoi.org/jesi/

2021 Volume 9 Number 1 (September)

http://doi.org/10.9770/jesi.2021.9.1(6)

\section{Introduction}

Current research on business growth strategies, emphasizes corporate entrepreneurship (CE) (Garvin \& Levesque, 2006; Morris, Kuratko, \& Covin, 2010) that benefits innovation (Freeman \& Engel, 2007; Kuratko, 2010). As a result, corporate entrepreneurship being part of entrepreneurship theory, has extended beyond change, strategic management, and innovation (McDougall \& Oviatt, 2000). Despite its extension, the corporate entrepreneurship researchers have only focused on the competitive advantages, profitable and sustainable over time (Hornsby, Kuratko, Shepherd, \& Bott, 2009; Kuratko, Ireland, Covin, \& Hornsby, 2005; Kuratko, Ireland, \& Hornsby, 2001; Morris et al., 2010), and on entrepreneurship behaviour (Wales, 2015), missing the opportunity of reviewing the topic as a holistic phenomenon (Ireland, Covin, \& Kuratko, 2009; Wales, 2015) and link with the enterprise environment (Kuratko, 2010).

Some researchers recognized the holistic comprehension of the phenomenon, as necessary, and suggest their approach (Escobar-Sierra, Valencia-DeLara, \& Vera-Acevedo, 2018). Fang (2013), for example, proposed the topic as a system with backgrounds or inputs (Zahra, 1986), transformations or process (Kuratko \& Audretsch, 2013) and outputs or effects (Cao, Simsek, \& Jansen, 2015; Zortea-Johnston, Darroch, \& Matear, 2012). For him, the system is encouraged by the market triggers i.e., competition, dynamism and heterogeneity in market demands (Zahra, 1991)-, and the stakeholders' needs (Amaeshi, Nnodim, \& Osuji, 2013; Carroll, 1999; Casson, 1982; Schwartz \& Carroll, 2003; Shanne \& Venkataraman, 2000). A context that turns on the system inputs, related to the organizational strategies i.e., governance policies (Bird, 1988), and organizational factors (Burgelman, 1983a) -i.e., culture, human resources practices (Hornsby et al., 2009), capacities and resources (Kuratko, Montagno, \& Hornsby, 1990), leadership characteristics (Ling, Simsek, Lubatkin, \& Veiga, 2008), information system (Kuratko, 2010), technological capabilities (Martín-Rojas, Fernández-Pérez, \& García-Sánchez, 2016) and company features (Álvarez-Herranz, Valencia-De-Lara, \& Martínez-Ruiz, 2011). Meanwhile, the process itself is related to the orientation or entrepreneurial behaviour, associated with innovation, risk-taking, and proactivity (Escobar-Sierra et al., 2018). Finally, the system outputs, associated with the stakeholders' satisfaction (BedoyaVilla \& Escobar-Sierra, 2018; Cao et al., 2015; Fang, 2013; Hernández Perlines, 2015; Zortea-Johnston et al., 2012), the main goal of social responsibility (Schwartz \& Carroll, 2003). Once discussed the conceptualization of the corporate entrepreneurship, next we review the future recommendations of some authors that recently analyzed the topic. Among them are Franco \& Haase (2017) who found that participative leadership style and job satisfaction has a significant effect over the collective entrepreneurship i.e., a conceptually more specific and detailed construct within the realm of corporate entrepreneurship. Moreover, he suggested it study into other geographical areas, paying particular attention to intercultural aspects. Urban \& Wood (2015) that highlight the importance of fostering opportunity recognition behaviours within an organization and motivating employees to act innovatively. Kuratko, McMullen, Hornsby, \& Jackson (2017) who first proposed and then suggested future validation of a new instrument that measures organizational antecedents for corporate social entrepreneurship. Hughes \& Mustafa (2017) that provide an incipient depiction of the internal environment for corporate entrepreneurship in emerging economy SMEs, finding that cultural and contextual factors influence the extent to which they can produce corporate entrepreneurship activity. Chebbi, Yahiaoui, Sellami, Papasolomou, \& Melanthiou (2019) that highlighted the vital role of internal stakeholders and internal marketing themes, as prerequisites for organizational change and the adoption of corporate entrepreneurship. Furthermore, Luu (2017) who relates corporate social responsibility, organizational citizenship behaviour for the environment, and corporate entrepreneurship as moderation mechanisms, finally suggests its future analysis, including value-based HR practices, among other things. Rexhepi, Abazi, Rahdari, \& Angelova (2019) suggest the future inclusion of entities, identified as "helices" in the innovation models. Because the organization is an open system, thus it creates benefits for others but also can use benefits from others. 


\section{ENTREPRENEURSHIP AND SUSTAINABILITY ISSUES}

ISSN 2345-0282 (online) http://jssidoi.org/jesi/ 2021 Volume 9 Number 1 (September) http://doi.org/10.9770/jesi.2021.9.1(6)

In this context, we question about how employees' job stress and career satisfaction impact the corporate entrepreneurship management linked to social responsibility in an IT Colombian company - classified as a big company - with presence in different countries. To that effect, the present study analyzes how employees' job stress and career satisfaction impact the corporate entrepreneurship management linked to social responsibility and present the findings in stages. This stage introduces the research context, the theoretical background, the problem, and the research question. The second stage presents a literature review and selection of the theoretical framework. The third section presents the methodological approach, where we compare or triangulate the results of artificial neural network and classification tree, and on the fourth stage presents the results and analysis. Finally, the fifth and sixth stages discuss the results with that of other authors and present the conclusions.

\section{Literature review and selection of the theoretical framework}

Despite the remote origin of entrepreneurship, that possibly emerge in the 16th century, only in the 20th century the official discussion about the concept began (Radović-Marković \& Salamzadeh, 2012). It can be said that this recent discussion and the theoretical development of corporate entrepreneurship has two significant milestones. The first milestone was the implicit inclusion of the term while referring to innovation models, as Freeman and Engel (2007) suggest when dividing innovation models between startups and mature companies. Moreover, the second one, related to the explicit adoption of corporate entrepreneurship as a research term (Peterson and Berger, 1971), and its consolidation as a research field (Kuratko, 2010). In this context, next, we propose a literature review that begins with some innovation models that include mature companies process in its definition - the first milestone, to end with a tour through the concept of $\mathrm{CE}$-the second milestone.

- Clark (1968) while analyzed institutionalization of innovations in higher education, criticized the traditional models -i.e., the organic growth model, the differentiation model, or the diffusion model-. To finally proposed the combined-process model that suggests as more appropriate for many situations.

- Langrish, Gibbons, Evans, \& Jevons (1972) while studying innovation in the industry, present a general discussion about the topic, some quantitative results, and several case studies. They finalize with the proposal of the innovation push model - related to discovery, and the pull model - related to demand.

- Mulkay (1975) discuss three models of the processes by which science develops -i.e., the model of openness, of closure, and of branching-. And argue that the third model provides social factors to scientific knowledge.

- Von Hippel (1978) propose the 'manufacturer-active' paradigm for which the manufacturer has the role of assessing customer needs and developing a responsive product idea. And the 'customer-active' paradigm in which the customer develops the new product idea and takes the initiative to transfer it to an interested manufacturer.

- Tornatzky et al. (1983) defined the 'technology source-centred models', i.e. based on basic research, applied research, development, testing or evaluating, manufacturing or packaging and marketing or dissemination, and the 'technology user-centred models', i.e. related to awareness, matching-selection, adoptioncommitment, implementation and routinization.

- Saren (1984) discusses the problems of a generalized innovation model, and review the advantages and disadvantages of the (a) Departmental-stage models, (b) Activity-stage models, (c) Decision-stage models, (d) Conversion process models, and (e) Response models. To conclude that more research needs to be concentrated on the nature of the innovation process within the firm itself.

- Pinch \& Bijker (1984) outlined the need for a social constructivist approach towards the study of science and technology. To finally, describe in more detail the two approaches, one in the sociology of scientific knowledge (EPOR), and one in the field of sociology of technology (SCOT).

- Kline \& Rosenberg (1986) criticized the models that consider innovation as a smooth and well-behaved linear process. To end, proposing innovation as a series of changes in a complete system not only of hardware, but also of market environment, production and knowledge facilities, and the social context of the organizational innovation. 


\section{ENTREPRENEURSHIP AND SUSTAINABILITY ISSUES}

ISSN 2345-0282 (online) http://jssidoi.org/jesi/

2021 Volume 9 Number 1 (September)

http://doi.org/10.9770/jesi.2021.9.1(6)

- Ziman (1991) criticized the general discourse about innovation exclusively based on the linear model. He also proposed another way of viewing the situation with a neural net model which allows for 'learning' to take place much as in the human brain.

- Rothwell (1992) traces developments in the models of industrial innovation from (1) the linear 'technology push' and 'need pull' model, (2) the 'coupling model', (3) the 'integrated model'. Until (4) the 4th Generation innovation process that perceived innovation as a parallel process. And, (5) the 5th generation model that involves inter-company networking, and employs a new electronic toolkit.

- Newby (1992) qualify as incomplete the so-called 'linear model' of science and propose an interactive model that takes into account as multidirectional the relationship between science, technology, and society.

- Freeman (1996) argues that world economy can move to a new and sustainable pattern of growth, through a new innovation model that combine some features of the much-criticized linear model - common in mature companies - with features of the systemic innovation model.

- Tait \& Williams (1999) defend the linear model of innovation as an essential driver of research and technology development (RTD) policies. And propose a linear-plus model which is reflected in policy initiatives such as (1) the promotion of industry-academic links, (2) special support for small and mediumsized firms and the (3) encouragement of more interdisciplinary approaches in the RTD process.

- Marinova \& Phillimore (2003) presents a historical examination of models used to explain innovation. Their overview includes six generations of models, namely black box, linear, interactive, systems, evolutionary models and innovative milieux. For each one, they presented the conceptualization background, the model itself and its elements, explanatory power, related models and concepts, and further research directions.

- Hargrave \& Van De (2006), when referring to institutional innovation, introduce a collective action model. That view institutional change as a dialectical process in which actors espouse conflicting views confront each other and engage in political behaviours to create and change institutions.

- Caraça, Lundvall, \& Mendonça (2009) they showed the change from a linear to the chain-linked model. To finally proposed a new model that summarizes the current research on the nature of economically useful knowledge, the diversity of intervening players in learning and the outcomes of innovation.

- Doloreux et al. (2019) evidenced that there is relatively little that is genuinely new in the different 'Territorial Innovation Models' in terms of theory-building and related concepts. This kind of models is also known as industrial districts, innovative milieu, learning regions, clusters, regional innovation systems, local production systems and new industrial spaces.

- Rexhepi, Abazi, Rahdari, \& Angelova (2019) described the triple helix that represents innovation system model where interact three 'helices' in knowledge production: universities-industry-governments.

- Soliman, Mogefors, \& Bergmann (2020) proposed what they called "problem-driven innovation models" to refer a more evidence-based and empirical mindset to drive valuable innovations with increased efficiency ultimately.

Meanwhile, and concerning the second milestone, next, we present a general tour through the clear concept of CE that begin in 1970. A period where researchers devoted to understanding the entrepreneurship within organizations and the risk team involved in its process. Then, during the 80's decade, the efforts were focused on the design and redesign of CE in the company (Burgelman, 1983b, 1983a, 1984). On the '90s the researches, study the skills that promoted innovation (Zahra, 1991). And finally, during the last two decades, the researches have focused on the combination of previously developed approaches, to understand how organizations obtain sustainable, profitable and competitive advantages over time (Hornsby et al., 2009; Morris et al., 2010; Lichtarski et al., 2020; Laužikas, Miliūtè, 2020). 


\section{Methodology}

Once defined the research problem and completed the literature review and selection of the theoretical framework, we present the research protocol proposed to solve the mentioned research question.

Table 1. Research protocol for the empirical verification.

\begin{tabular}{|c|c|}
\hline Criteria & Quantitative approach \\
\hline Role of the theory & Deductive \\
\hline Research strategy & Case study \\
\hline Unit of Analysis & Job stress and career satisfaction \\
\hline Sample & 110 employees of an IT company in Colombia \\
\hline Variables & $\begin{array}{l}\text { Dependent variable -i.e., y- (Idea quality measure related to company stakeholder's needs (in } \\
\text { the social responsibility framework)) and independent variables -i.e., x- (employees' job } \\
\text { stress, career satisfaction and other demographic variables). }\end{array}$ \\
\hline Gathering of data & $\begin{array}{c}\text { Variables: education level (Pernelle, Carron, Elkadiri, Bissay, \& Marty, 2014:323-332), } \\
\text { Quality metric for generated ideas (Reinig \& Briggs, 2013:943-973) (Likert scale for SR } \\
\text { criteria), gender, age and years of service (Chiavenato, 2008). } \\
\text { Instrument: Shukla \& Srivastava (2016) survey of job stress and Greenhaus, Parasuraman, \& } \\
\text { Wormley (1990) survey of career satisfaction. }\end{array}$ \\
\hline Analysis of results & $\begin{array}{c}\text { Machine learning methods: } \\
\text { Artificial neural network (Nisbet, Miner, \& Elder, 2009) } \\
\text { Classification tree (Bramer, 2007) }\end{array}$ \\
\hline Results & $\begin{array}{c}\text { Employees' job stress and career satisfaction factors that influence idea quality related to social } \\
\text { responsibility. }\end{array}$ \\
\hline
\end{tabular}

The data was collected in 2018, between 110 employees of an IT company in Medellín-Colombia-South America, born between 1963 to $2001.56 .4 \%$ of the respondents have a professional career, and $60.9 \%$ correspond with men. During the fieldwork, all employees were asked a real problem of the company creatively, while other data was gathered.

\section{Results and analysis}

For the analysis of the results, we apply a triangulation, i.e. an alternative of validation where can combine multiple methods, empirical materials, perspectives and observers in a single study as a strategy that adds rigour, breadth, and depth to any investigation (Denzin \& Lincoln, 2008, p. 3; Flick, 1992). Specifically, a method triangulation where we compare the results of an artificial neural network (ANN) and the classification or decision trees. Two techniques that deliver the importance of each one of the variables as results, once verified the significance and accuracy of the models.

The artificial neural network (ANN) is a computational system that works like the human brain, passing impulses from neuron to neuron across synapses (Nisbet et al., 2009). This technique can be configured to function as a binary classifier (yes/no or 1/0) or as a regression index (for numerical outputs) or and also to contain multiple output nodes for estimation, classification or even as a clustering algorithm (Nisbet et al., 2009). While the decision or classification trees, the most popular technique in data mining, help to generate classification rules through a treelike structure (Bramer, 2007), used to predict and compress data (Bramer, 2007). Next, we present the results of each technique. 


\subsection{Results and analysis of the artificial neural networks}

The artificial neural network is configured as follow:

- The objective of the model is to discover how employees' job stress, measured with the test of Shukla \& Srivastava (2016), and career satisfaction, measured with the test of Greenhaus, Parasuraman, \& Wormley (1990), impact the quality of the idea, scores of Likert scale proposed by Reinig and Briggs (2013) related to social responsibility. Model in which job stress and career satisfaction act as independent variables, while the idea quality related to social responsibility acts as the dependent variable.

- Artificial neural network (ANN): multilayer perceptron.

- Sample: 110 employees

- The ANN configuration has 114 units, with 1 hidden layer and 15 units in the hidden layers. The activation function corresponds to the hyperbolic tangent with one dependent variable. The number of units is 4 , the activation function is softmax, and the error function is a cross-entropy.

- Dependent variables: a measure of idea quality (Reinig \& Briggs, 2013) defined as a Likert scale associated with social responsibility issues (denoted by the letter Y).

- Independent variables: 21 items of Shukla \& Srivastava's (2016) test (denoted by the letter X) and five items of Greenhaus, Parasuraman, \& Wormley's (1990) test (denoted by the letter Z).

- Demographic variables such as age, gender, education level and years of service.

Table 1 shows the results of the ANN that has a cross-entropy error of 37.497 during the training; the percentage of the incorrect forecast is $17.3 \%$, and the stop rule is one time.

Table 1. Percentage of correct results that reaches the artificial neural network for each quality measure during the training

\begin{tabular}{|c|c|}
\hline Quality measure & Correct percentage \\
\hline Null & $77.8 \%$ \\
\hline Low & $83.3 \%$ \\
\hline Medium & $86.7 \%$ \\
\hline High & $66.7 \%$ \\
\hline Gl obal & $82.7 \%$ \\
\hline \multicolumn{2}{|c|}{ Source: created by the authors using $\operatorname{SPSS}{ }^{\circledR}$} \\
\hline
\end{tabular}

As a useful measure of accuracy, Figure 1 shows the plot of sensitivity versus 1 - Specifity, known as receiver operating characteristic (ROC) curve (Hajian-Tilaki, 2013). 


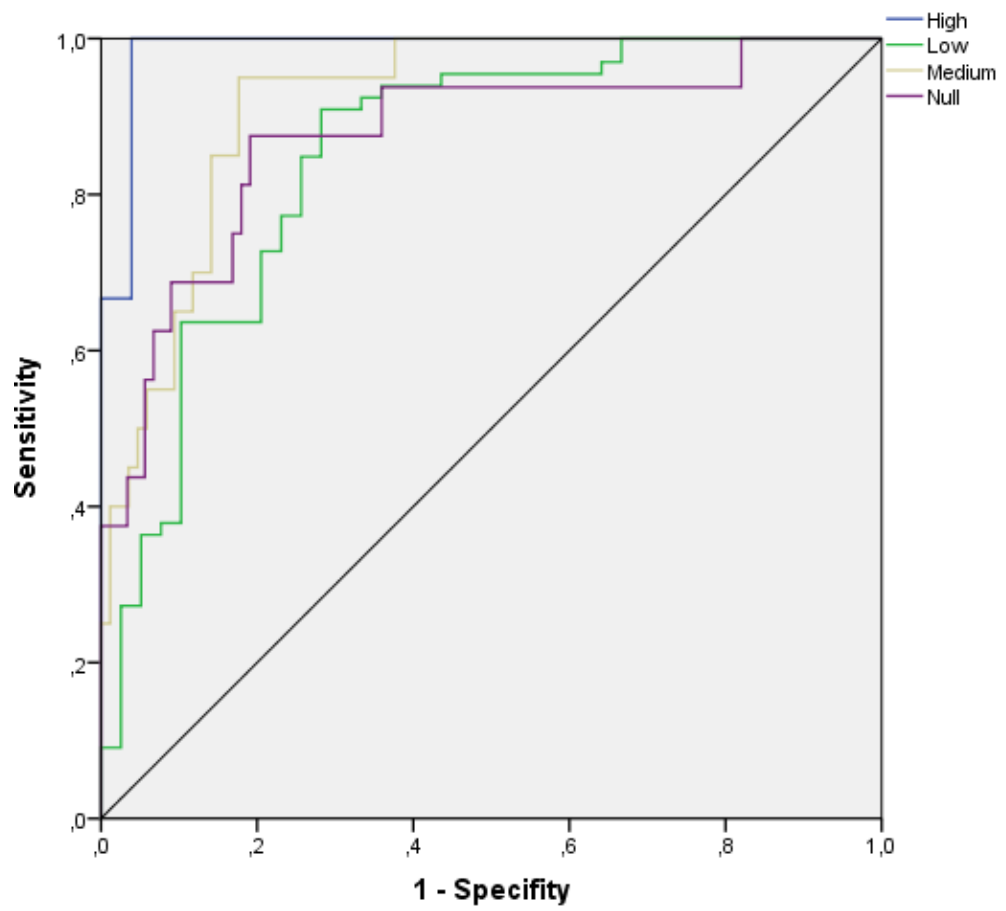

Figure 1. ROC curve for the artificial neural network Source: created by the authors using SPSS ${ }^{\circledR}$

Next, in Table 2, we present the area under the curve, shown in Figure 1, for each of the quality measures (null, low, medium and high).

Table 2. Area down the curve for each quality measure

\begin{tabular}{|c|c|}
\hline Quality measure & Area down the curve \\
\hline Null & .847 \\
\hline Low & .850 \\
\hline Medium & .918 \\
\hline High & .987 \\
\hline \multicolumn{2}{|c|}{ Source: created by the authors using SPSS }
\end{tabular}

Once verified the accuracy of the model, next, we present in Table 3, the estimated importance of each independent variable in the ANN.

Table 3. Importance of each independent variable in the artificial neural network

\begin{tabular}{|c|c|}
\hline Independent variables & Importance \\
\hline Gender &, 026 \\
\hline Age &, 057 \\
\hline Education level &, 038 \\
\hline Years of service &, 044 \\
\hline X1 &, 038 \\
\hline X2 &, 031 \\
\hline X3 &, 040 \\
\hline X4 &, 053 \\
\hline X5 &, 025 \\
\hline X6 &, 027 \\
\hline X7 &, 021 \\
\hline
\end{tabular}


ENTREPRENEURSHIP AND SUSTAINABILITY ISSUES

ISSN 2345-0282 (online) http://jssidoi.org/jesi/ 2021 Volume 9 Number 1 (September) http://doi.org/10.9770/jesi.2021.9.1(6)

\begin{tabular}{|c|c|}
\hline Independent variables & Importance \\
\hline $\mathrm{X} 8$ &, 034 \\
\hline $\mathrm{X} 9$ &, 025 \\
\hline $\mathrm{X} 10$ &, 023 \\
\hline $\mathrm{X} 11$ &, 035 \\
\hline $\mathrm{X} 12$ &, 027 \\
\hline $\mathrm{X} 13$ &, 046 \\
\hline $\mathrm{X} 14$ &, 043 \\
\hline $\mathrm{X} 15$ &, 022 \\
\hline $\mathrm{X} 16$ &, 043 \\
\hline $\mathrm{X} 17$ &, 019 \\
\hline $\mathrm{X} 18$ &, 029 \\
\hline $\mathrm{X} 19$ &, 034 \\
\hline $\mathrm{X} 20$ &, 038 \\
\hline $\mathrm{X} 21$ &, 020 \\
\hline $\mathrm{Z} 1$ &, 039 \\
\hline $\mathrm{Z} 2$ &, 033 \\
\hline $\mathrm{Z3}$ &, 036 \\
\hline $\mathrm{Z} 4$ &, 026 \\
\hline $\mathrm{Z} 5$ &, 028 \\
\hline
\end{tabular}

Source: created by the authors using SPSS®

X1 - "I have much work, and I am afraid there is very little time to do it." X2 - "I feel so overwhelmed that even a day without work seems bad."X3 - "I feel like I never leave my job." X4 - "Many people in my office are tired of the company's demand." X5 - "My job makes me nervous." X6 - "The effect of my work on me is too high. Many times, my work becomes too much of a burden. X7 - "Sometimes, when I think about my work, I get a feeling that my chest is being squeezed." X8 - "I feel bad when I leave my job." X9 - "I am not able to satisfy the different requests of my bosses." X10 - "I cannot solve the conflicts with my colleagues." X11 - "I cannot satisfy my customers' requests, because they are opposite to each other" X12 - "My bosses' expectations are different from my subordinates" X13 - "I am concerned about the expectations of different people." X14 - "My co-workers share information with me, they explain." X15 "My co-workers understand me. They give me advice." X16 - "I have received clear and useful recommendations about my work." X17 - "I have received help in my work." X18 - "I can balance time at work and time in other activities." X19 - "I have difficulty balancing my work and other activities". X20 - "I feel that work and other activities are currently balanced." X21 - "In general, I think my work and other activities are balanced." And Z1 - "I am satisfied with the success I have achieved in my career." Z2 - "I am satisfied with the progress I have made in achieving my professional goals." Z3 - "I am pleased with the progress I have made in achieving my income goals." Z4 - "I am pleased with the progress I have made toward my career goals." Z5 - "I am pleased with the progress I have made in achieving my goals for new skill development."

The first ten independent variables or demographic data (listed in Table 3 in italics font) represent the most critical variables, those that more contribute to the idea quality metric in the ANN analysis. These ten most influential variables of the ANN will be compared or triangulated with the ten most influential variables of the classification tree, in the next section.

\subsection{Results and analysis of the classification trees}

The classification tree is configured as follow:

- The objective of the model is to discover how employees' job stress, measured with the test of Shukla \& Srivastava (2016), and career satisfaction, measured with the test of Greenhaus, Parasuraman, \& Wormley (1990), impact the quality of the idea, scores of Likert scale proposed by Reinig and Briggs (2013) related to social responsibility. Model in which job stress and career satisfaction act as independent variables, while the idea quality related to social responsibility acts as the dependent variable.

- Growing method for the classification tree: CRT

- Sample: 110 employees

- Maximum tree depth, 10; minimum number of cases in a final node, 8; minimum number of cases in a parental node, 2.

- Dependent variables: a measure of idea quality (Reinig \& Briggs, 2013) defined as a Likert scale associated with social responsibility issues (denoted by the letter Y).

- Independent variables: 21 items of Shukla \& Srivastava's (2016) test (denoted by the letter X) and five items of Greenhaus, Parasuraman, \& Wormley's (1990) test (denoted by the letter Z).

- Demographic variables such as age, gender, education level and years of service. 
Finally, this stage presents the resulting classification tree that has 25 nodes, 13 terminal nodes and a depth of 6 and reaches correct results in the $79,1 \%$ of times, as is shown in Table 4, which shows the percentage of correct results reached for each quality measure.

Table 4. Percentage of correct results that reach the classification tree for each quality measure

\begin{tabular}{|c|c|}
\hline Quality measure & Correct percentage \\
\hline Null & $50.0 \%$ \\
\hline Low & $91.3 \%$ \\
\hline Medium & $63.6 \%$ \\
\hline High & $66.7 \%$ \\
\hline Global & $79.1 \%$ \\
\hline
\end{tabular}

Source: created by the authors using $\operatorname{SPSS}{ }^{\circledR}$

Once verified the accuracy of the model, we present in Table 5, the estimated importance of each independent variable in the classification tree.

Table 5. Importance of each independent variable in the classification tree

\begin{tabular}{|c|c|}
\hline Independent variables & Importance \\
\hline $\mathrm{X} 3$ & ,046 \\
\hline $\mathrm{X} 7$ &, 045 \\
\hline Age &, 045 \\
\hline $\mathrm{X} 11$ & ,038 \\
\hline $\mathrm{X} 18$ & 034 \\
\hline $\mathrm{X} 2$ & ,031 \\
\hline $\mathrm{X} 21$ & ,031 \\
\hline $\mathrm{Z1}$ & ,028 \\
\hline Years of service & ,027 \\
\hline X19 & ,027 \\
\hline $\mathrm{X} 16$ & ,026 \\
\hline $\mathrm{X} 9$ &, 025 \\
\hline Education level &, 025 \\
\hline X6 &, 025 \\
\hline $\mathrm{X} 5$ & ,024 \\
\hline $\mathrm{X} 13$ & ,024 \\
\hline $\mathrm{Z} 5$ & ,023 \\
\hline $\mathrm{X} 4$ & ,019 \\
\hline $\mathrm{Z3}$ & 014 \\
\hline $\mathrm{Z} 2$ & ,013 \\
\hline $\mathrm{X} 1$ &, 012 \\
\hline $\mathrm{X} 14$ & ,011 \\
\hline $\mathrm{X} 12$ &, 010 \\
\hline $\mathrm{X} 17$ & ,007 \\
\hline $\mathrm{X} 10$ &, 004 \\
\hline $\mathrm{Z4}$ &, 003 \\
\hline $\mathrm{X} 15$ & ,001 \\
\hline
\end{tabular}

Source: created by the authors using SPSS ${ }^{\circledR}$

X1 - "I have much work, and I am afraid there is very little time to do it."X2 - "I feel so overwhelmed that even a day without work seems bad."X3 - "I feel like I never leave my job." X4 - "Many people in my office are tired of the company's demand." X5 - "My job makes me nervous." X6 - "The effect of my work on me is too high. Many times, my work becomes too much of a burden. X7 - "Sometimes, when I think about my work, I get a feeling that my chest is being squeezed." X8 - "I feel bad when I leave my job." X9 - "I am not able to satisfy the different requests of my bosses." X10 - "I cannot solve the conflicts with my colleagues." X11 - "I cannot satisfy my customers' requests, because they are opposite to each other" X12 - "My bosses' expectations are different from my subordinates" X13 - "I am concerned about the expectations of different people." X14 - "My co-workers share information with me, they explain." X15 "My co-workers understand me. They give me advice." X16 - "I have received clear and useful recommendations about my work." X17 - "I have received help in my work." X18 - "I can balance time at work and time in other activities." X19 - "I have difficulty balancing my work and other activities". X20 - "I feel that work and other activities are currently balanced." X21 - "In general, I think my work and other activities are balanced." And Z1 - "I am satisfied with the success I have achieved in my career." Z2 - "I am satisfied with the progress I have made in achieving my professional goals." Z3 - "I am pleased with the progress I have made in achieving my income goals." Z4 - "I am pleased with the progress I have made toward my career goals." Z5 - "I am pleased with the progress I have made in achieving my goals for new skill development." 


\section{ENTREPRENEURSHIP AND SUSTAINABILITY ISSUES}

ISSN 2345-0282 (online) http://jssidoi.org/jesi/

2021 Volume 9 Number 1 (September)

http://doi.org/10.9770/jesi.2021.9.1(6)

The first ten independent variables or demographic data (listed in Table 6 in italics font) are the most influential, those that contribute the maximum to the dependent variable in the classification tree analysis. Five of these 10 influential variables are common or recurrent between ANN results and classification tree results (green highlighted variables of Table 3 and Table 5). Methodological triangulation that suggests the following independent or demographic variables (1) X3 "I feel that I never take a leave". (2) X7 "Many times, my job becomes a big burden". (3) Age. (4) X2 "I feel so burdened that even a day without work seems bad". Moreover, (5) years of service as the most influential variables over the idea quality associated with social responsibility issues.

Where we can highlight the incidence of job stress i.e., with three of the five commons, and most influential variables- and the absence of career satisfaction factors on idea quality. The job stress survey that we applied was proposed by Shukla \& Srivastava (2016, p. 10). It is divided into different scales, as follows (a.) job stress, (b.) role expectation conflict, (c.) co-worker support and (d.) work-life balance. The most influential variables are all on the first scale, related to the job stress. And, concerning the demographic variables, age and years of service acts as an inhibitor or promoter of the corporate entrepreneurship, showing a real influence.

\section{Discussion with other authors}

The present study focuses on the innovation process within the firm itself, as Saren (1984) suggests, and consider the social context of the organizational innovation that highlights Kline \& Rosenberg (1986). Our analysis of the impact of job stress and career satisfaction over the corporate entrepreneurship management linked to social responsibility agrees with the recent recommendations of Franco \& Haase (2017) that proposed the future inclusion of intercultural aspects while analyzed the job satisfaction. Kuratko, McMullen, Hornsby, \& Jackson (2017) that talked about corporate social entrepreneurship, bridging this kind of entrepreneurship with the social context. Chebbi, Yahiaoui, Sellami, Papasolomou, \& Melanthiou (2019) that highlighted the important role of internal stakeholders as employees, also recognizing the externals (Rexhepi et al., 2019). Caraça, Lundvall, \& Mendonça (2009) that promoted the diversity of intervening players in learning and the outcomes of innovation. And Luu (2017) that has also related social responsibility with corporate entrepreneurship. Our methodological proposal responses to Ziman (1991) recommendation of modelling innovation through a neural net model. And, the independent variable also attends to Soliman, Mogefors, \& Bergmann (2020) recommendation, of including a problem-driven innovation.

Nevertheless, the obtained results disagree with the proposals of other authors like Urban \& Wood (2015) that favours only the opportunity recognition behaviours among employees. Hughes \& Mustafa (2017) that study emergence economies - like the Colombian one, but only focused on the corporate entrepreneurship in SMEs. Hargrave \& Van De (2006) for whom innovation is a dialectical process in which actors espouse conflicting views confront each other. And Von Hippel (1978) who propose the 'manufacturer-active' paradigm i.e., for which the manufacturer has the role of assessing customer needs and developing a responsive product idea, and the 'customer-active' paradigm, i.e., in which the customer develops the new product idea and takes the initiative to transfer it to an interested manufacturer. 


\section{ENTREPRENEURSHIP AND SUSTAINABILITY ISSUES}

ISSN 2345-0282 (online) http://jssidoi.org/jesi/

2021 Volume 9 Number 1 (September)

http://doi.org/10.9770/jesi.2021.9.1(6)

\section{Conclusions and recommendations}

Only the job stress impact the corporate entrepreneurship management linked to social responsibility, while career satisfaction does not seem to have significant effects over it, in the IT Company. The job stress mentioned refers, in this case, to the physical stress derived from the work, not to the stress resulting from the role expectation conflict, the co-worker support, and the work-life balance. In the selected case of the IT Colombian company, the corporate entrepreneurship management linked to social responsibility also seems related to demographic variables like the age and the years of service. A meaningful finding for the corporate entrepreneurship and social responsibility field that can be taken into account in future meta-analysis reviews. Furthermore, a useful finding for managers that believe in employees as the main actor of cooperative innovation models.

The methodological triangulation - like the one applied - where can be combined, between others, multiple methods, results as an efficient strategy to add rigour, breadth, and depth to research. In our case, we compare the results of the artificial neural network (ANN) and the classification or decision trees, once verified the significance and accuracy of the models. During this triangulation, we compare the ten most important independent variable in the artificial neural network model with the ten of the classification trees, where we find five common variables in both models.

Despite the remote origin of entrepreneurship, that possibly emerge in the 16th century, only in the 20th century the official discussion about the concept took place. This discussion about the topic has two big milestones, the first one related to the implicit inclusion of the term while referring to innovation models, where it is important to highlight the absence of a generalized model. And the second one related to the explicit adoption of corporate entrepreneurship as a research term, where the focus is on understanding how organizations obtain sustainable, profitable and competitive advantages over time.

The link that we propose between corporate entrepreneurship management and social responsibility consider the different stakeholders' needs during the idea generation process, as part of a problem-driven innovation. Our conception of social responsibility takes into account legal, economic and environmental issues, in a particular context where ethical and sustainability values are essential in the resolution of stakeholders' needs. However, in our research, the evaluation of social responsibility only considers the idea generation process, so for future research, it could be taken into account other corporate entrepreneurship phases, as design, production, commercialization, after-sales, and disposal phases. Another gap in our research relates to the inclusion of only one stakeholder, the employees, who tried to solve different stakeholders' needs. In the future, we can consider the perspective of different stakeholders.

For future researches, we suggest the verification of other backgrounds of corporate entrepreneurship related, for example, with organizational strategies, and with different organizational factors to those analyzed here. In this sense, it would also be possible to review the corporate entrepreneurship process with behaviours associated with the risk-taking and proactivity. And with the corporate entrepreneurship outcomes, related to the organizational performance link to the satisfaction of different stakeholders. Finally, we highlighted the inclusion of different stakeholders in the corporate entrepreneurship management, for example, the shareholders, the suppliers, the clients, the academies, and the state. 


\section{ENTREPRENEURSHIP AND SUSTAINABILITY ISSUES}

ISSN 2345-0282 (online) http://jssidoi.org/jesi/ 2021 Volume 9 Number 1 (September) http://doi.org/10.9770/jesi.2021.9.1(6)

\section{References}

Álvarez-Herranz, A., Valencia-De-Lara, P., \& Martínez-Ruiz, M. P. (2011). How entrepreneurial characteristics influence company creation: a cross-national study of 22 countriestested with panel data methodology. Journal of Business Economics and Management, 12(3), 529-545. https://doi.org/10.3846/16111699.2011.599409

Amaeshi, K., Nnodim, P., \& Osuji, O. (2013). Corporate social responsibility, entrepreneurship, and innovation. New York: Routledge. https://doi.org/10.4324/9780203081945

Bedoya-Villa, M. A., \& Escobar-Sierra, M. (2018). Impact of Employees' Attitudes and Leader's Role on the Innovation Management Linked to Social Responsibility. Quality Innovation Prosperity, 22(2), 65-81. https://doi.org/10.12776/qip.v22i2.1121

Bird, B. (1988). Implementing entrepreneurial ideas: the case for intention. Academy of Management Review, 13(3), 442-453. https://doi.org/10.5465/AMR.1988.4306970

Bramer, M. (2007). Principles of Data Mining. (I. Mackie, Ed.). London: Springer.

Burgelman, R. (1983a). A process model of internal corporate venturing in the diversified major firm. Administrative Science Quarterly, 28(2), 223-244. https://doi.org/10.2307/2392619

Burgelman, R. (1983b). Corporate entrepreneurship and strategic management: insights from a process study. Management Science, 29(12), 1349-1364. https://doi.org/10.1287/mnsc.29.12.1349

Burgelman, R. (1984). Designs for corporate entrepreneurship in established firm. California Management Review, 26(3), 154-166. https://doi.org/10.2307/41165086

Cao, Q., Simsek, Z., \& Jansen, J. J. P. (2015). CEO social capital and entrepreneurial orientation of the firm: bonding and bridging effects. Journal of Management, 41(7), 1957-1981. https://doi.org/10.1177/0149206312469666

Caraça, J., Lundvall, B.-Å., \& Mendonça, S. (2009). The changing role of science in the innovation process: From Queen to Cinderella? Technological Forecasting and Social Change, 76(6), 861-867. https://doi.org/10.1016/j.techfore.2008.08.003

Carroll, A. B. (1999). Corporate Social Responsibility: Evolution of a Definitional Construct. Business \& Society, 38(3), 268-295. https://doi.org/10.1177/000765039903800303

Casson, M. (1982). The entrepreneur: an economic theory. (Rowman \& Littlefield, Ed.). Totowa, New Jersey: Barnes \& noble books.

Chebbi, H., Yahiaoui, D., Sellami, M., Papasolomou, I., \& Melanthiou, Y. (2019). Focusing on internal stakeholders to enable the implementation of organizational change towards corporate entrepreneurship: A case study from France. Journal of Business Research. https://doi.org/10.1016/J.JBUSRES.2019.06.003

Chiavenato, I. (2008). Gestión del talento humano. Gestión del Talento Humano. México: McGraw Hill. https://doi.org/10.1017/CBO9781107415324.004

Clark, T. N. (1968). Institutionalization of innovations in higher education: four models. Administrative Science Quarterly, 13(1), 1-25. https://doi.org/10.2307/2391259

Denzin, N. K., \& Lincoln, Y. S. (2008). The landscape of qualitative research. (N. K. Denzin \& Y. S. Lincoln, Eds.), Handbook of qualitative research (Vol. 1). Thousand Oaks, CA, US: Sage Publications, Inc.

Escobar-Sierra, M., Valencia-DeLara, P., \& Acevedo-Vera, L. D. (2018). A New Corporate Entrepreneurship Knowledge Schema as a Research Field. Academy of Entrepreneurship Journal, 24(4), 1-13. Retrieved from https://www.abacademies.org/articles/A-newcorporate-entrepreneurship-knowledge-schema-as-a-research-field-1528-2686-24-4-182.pdf 


\section{ENTREPRENEURSHIP AND SUSTAINABILITY ISSUES}

ISSN 2345-0282 (online) http://jssidoi.org/jesi/ 2021 Volume 9 Number 1 (September) http://doi.org/10.9770/jesi.2021.9.1(6)

Fang, Q. (2013). Corporate entrepreneurship: constructs and research focuses. In E. Qi, J. Shen, \& R. Dou (Eds.), The 19th international conference on industrial engineering and engineering management (pp. 699-706). Berlin, Heidelberg: Springer Berlin Heidelberg. https://doi.org/10.1007/978-3-642-38442-4

Flick, U. (1992). Triangulation Revisited: Strategy of Validation or Alternative? Journal for the Theory of Social Behaviour, 22(2), 175197. https://doi.org/10.1111/j.1468-5914.1992.tb00215.x

Franco, M., \& Haase, H. (2017). Collective entrepreneurship: Employees' perceptions of the influence of leadership styles. Journal of Management and Organization, 23(2), 241-257. https://doi.org/10.1017/jmo.2016.3

Freeman, J., \& Engel, J. S. (2007). Models of innovation: startups and mature corporations. California Management Review, 50(1), 94119. https://doi.org/10.2307/41166418

Garvin, D. A., \& Levesque, L. C. (2006). Meeting the challenge of corporate entrepreneurship. Harvard Business Review, 84(10), 102-112, 150.

Greenhaus, J. H., Parasuraman, S., \& Wormley, W. M. (1990). Effects of Race on Organizational Experiences, Job Performance Evaluations, and Career Outcomes. Academy of Management Journal, 33(1), 64-86. https://doi.org/10.2307/256352

Hajian-Tilaki, K. (2013). Receiver Operating Characteristic (ROC) Curve Analysis for Medical Diagnostic Test Evaluation. Caspian Journal of Internal Medicine, 4(2), 627-635. Retrieved from http://www.ncbi.nlm.nih.gov/pubmed/24009950

Hargrave, T. J., \& Van De, A. H. (2006). A collective action model of institutional innovation. Academy of Management Review, 31(4), 864-888. https://doi.org/10.5465/AMR.2006.22527458

Hernández Perlines, F. (2015). El efecto mediador de la RSE en la relación de la orientación emprendedora y el desempeño de las cooperativas agroalimentarias. CIRIEC - España. Revista de Economía Pública, Social y Cooperativa, (85), 217-244. https://doi.org/0213$\underline{8093}$

Hornsby, J. S., Kuratko, D. F., Shepherd, D. A., \& Bott, J. P. (2009). Managers' corporate entrepreneurial actions: examining perception and position. Journal of Business Venturing, 24(3), 236-247. https://doi.org/10.1016/j.jbusvent.2008.03.002

Hughes, M., \& Mustafa, M. (2017). Antecedents of Corporate Entrepreneurship in SMEs: Evidence from an Emerging Economy. Journal of Small Business Management, 55, 115-140. https://doi.org/10.1111/jsbm.12269

Ireland, R. D., Covin, J. G., \& Kuratko, D. F. (2009). Conceptualizing corporate entrepreneurship strategy. Entrepreneurship Theory and Practice, 33(1), 19-46. https://doi.org/10.1111/j.1540-6520.2008.00279.x

Kline, S. J., \& Rosenberg, N. (1986). An overview of innovation. In Ralph Landau \& Nathan Rosenberg (Eds.), The Positive Sum Strategy: Harnessing Technology for Economic Growth (pp. 275-305). Washington: National Academy Press.

Kuratko, D. F. (2010). Corporate entrepreneurship: an introduction and research review. In Z. J. Acs \& D. B. Audretsch (Eds.), Handbook of Entrepreneurship Research (pp. 129-163). New York, NY: Springer New York. https://doi.org/10.1007/978-1-4419-1191-9

Kuratko, D. F., \& Audretsch, D. B. (2013). Clarifying the domains of corporate entrepreneurship. International Entrepreneurship and Management Journal, 9(3), 323-335. https://doi.org/10.1007/s11365-013-0257-4

Kuratko, D. F., Ireland, R. D., \& Hornsby, J. S. (2001). The power of entrepreneurial outcomes: insights from Acordia. Academy of Management Executive, 15(4), 60-71.

Kuratko, D. F., Ireland, R. D., Covin, J. G., \& Hornsby, J. S. (2005). A model of middle-level managers' entrepreneurial behavior. Entrepreneurship Theory and Practice, 29(6), 699-716. https://doi.org/10.1111/j.1540-6520.2005.00104.X

Kuratko, D. F., McMullen, J. S., Hornsby, J. S., \& Jackson, C. (2017). Is your organization conducive to the continuous creation of social value? Toward a social corporate entrepreneurship scale. Business Horizons, 60(3), 271-283. https://doi.org/10.1016/J.BUSHOR.2016.12.003 


\section{ENTREPRENEURSHIP AND SUSTAINABILITY ISSUES}

ISSN 2345-0282 (online) http://jssidoi.org/jesi/ 2021 Volume 9 Number 1 (September) http://doi.org/10.9770/jesi.2021.9.1(6)

Kuratko, D. F., Montagno, R. V, \& Hornsby, J. S. (1990). Developing an intrapreneurial assessment instrument for an effective corporate entrepreneurial environment. Strategic Management Journal, 11(Special Issue), 49-58.

Laužikas, M., \& Miliūtè, A. (2020). Liaisons between culture and innovation: comparative analysis of South Korean and Lithuanian IT companies. Insights into Regional Development, 2(2), 523-537. https://doi.org/10.9770/IRD.2020.2.2(2)

Langrish, J., Gibbons, M., Evans, W., \& Jevons, F. . (1972). Wealth from knowledge: studies of innovation in industry. London: The Macmillan Press.

Lichtarski, J.M., Piorkowska, K., \& Cwik, K. (2019). The Intensity of Inter-organizational Relationships and the Strategic Flexibility of Nodal Organizations. Transformations in Business \& Economics, 18, No 2B (47B), 709-727.

Ling, Y., Simsek, Z., Lubatkin, M. H., \& Veiga, J. F. (2008). Transformational leadership's role in promoting corporate entrepreneurship: Examining the CEO-TMT interface. Academy of Management Journal, 51(3), 557-576.

Luu, T. T. (2017). CSR and organizational citizenship behavior for the environment in hotel industry. International Journal of Contemporary Hospitality Management, 29(11), 2867-2900. https://doi.org/10.1108/IJCHM-02-2016-0080

Marinova, D., \& Phillimore, J. (2003). Models of innovation. In L. V. Shavinina (Ed.), The international handbook on innovation (pp. 4453). Oxford: Elsevier.

Martín-Rojas, R., Fernández-Pérez, V., \& García-Sánchez, E. (2016, July 28). Encouraging organizational performance through the influence of technological distinctive competencies on components of corporate entrepreneurship. International Entrepreneurship and Management Journal, pp. 1-30. https://doi.org/10.1007/s11365-016-0406-7

McDougall, P. P., \& Oviatt, B. M. (2000). International entrepreneurship: The intersection of two research paths. Academy of Management Journal, 43(5), 902-906. https://doi.org/10.2307/1556418

Morris, M., Kuratko, D., \& Covin, J. (2010). Corporate entrepreneurship \& innovation. (M. S. Acuna, Ed.) (3rd ed.). Mason, Ohio: Cengage Learning.

Mulkay, M. J. (1975). Three models of scientific development. The Sociological Review, 23(3), 509-526. https://doi.org/10.1111/j.1467954X.1975.tb02231.x

Newby, H. (1992). One society, one Wissenschaft: A 21st Century vision. Science and Public Policy, 19(1), 7-14. https://doi.org/10.1093/spp/19.1.7

Nisbet, R., Miner, G., \& Elder, J. (2009). Handbook of Statistical Analysis and Data Mining Applications (2nd ed.). Academic Press. https://doi.org/10.1016/B978-0-12-374765-5.00023-1

Pernelle, P., Carron, T., Elkadiri, S., Bissay, A., \& Marty, J. C. (2014). PLM serious game approach available both for change management and knowledge assessment. In S. Fukuda, A. Bernard, B. Gurumoorthy, \& A. Bouras (Eds.), Product lifecycle management for a global market, 442, pp. 323-332. Japan: Springer Berlin Heidelberg. https://doi.org/10.1007/978-3-662-45937-9_32

Peterson, R. A., \& Berger, D. G. (1971). Entrepreneurship in organizations: evidence from the popular music industry. Administrative Science Quarterly, 16(1), 97-106. https://doi.org/10.2307/2391293

Pinch, T. J., \& Bijker, W. E. (1984). The Social Construction of Facts and Artefacts: Or How the Sociology of Science and the Sociology of Technology Might Benefit Each Other. Social Studies of Science, 14(3), 399-441.

Radović-Marković, M., \& Salamzadeh, A. (2012). The Nature Of Entrepreneurship: Entrepreneurs and Entrepreneurial Activities. (D. Simandan \& M. Omolaja, Eds.) (1st ed.). Lap Lambert Academic Publishing.

Reinig, B. A., \& Briggs, R. O. (2013). Putting quality first in ideation research. Group Decision and Negotiation, 22(5), 943-973. https://doi.org/10.1007/s10726-012-9338-y

Rothwell, R. (1992). Successful industrial innovation: critical factors for the 1990s. R\&D Management, 22(3), $221-239$. 


\section{ENTREPRENEURSHIP AND SUSTAINABILITY ISSUES}

ISSN 2345-0282 (online) http://jssidoi.org/jesi/ 2021 Volume 9 Number 1 (September) http://doi.org/10.9770/jesi.2021.9.1(6)

Saren, M. A. (1984). A classification and review of process models of innovation. R\&D Management, 14(1), 11-24. https://doi.org/10.1111/j.1467-9310.1984.tb00504.x

Schwartz, M. S., \& Carroll, A. B. (2003). Corporate social responsibility: a three-domain approach. Business Ethics Quarterly, 13(4), 503530. https://doi.org/10.2307/3857969

Schwartz, S. H. (1987). An invitation to collaborate in crosscultural research on values. Jerusalem.

Shanne, S., \& Venkataraman, S. (2000). The promise of entrepreneurship as a field of research. Academy of Management Review, 25(1), 217-226. https://doi.org/10.5465/AMR.2000.2791611

Shukla, A., \& Srivastava, R. (2016). Development of short questionnaire to measure an extended set of role expectation conflict, coworker support and work-life balance: The new job stress scale. Cogent Business and Management, 3(1). https://doi.org/10.1080/23311975.2015.1134034

Tait, J., \& Williams, R. (1999). Policy approaches to research and development: foresight, framework and competitiveness. Science and Public Policy, 26(2), 101-112. https://doi.org/10.3152/147154399781782536

Tornatzky, L. G., Eveland, J., Hoylan, M. G., Hetzner, W. A., Johnson, E. C., Roitman, D., \& Schneider, J. (1983). The process of technological innovation reviewing the literature. Washington: National Science Foundation.

Urban, B., \& Wood, E. (2015). The importance of opportunity recognition behaviour and motivators of employees when engaged in corporate entrepreneurship. Journal of Business Economics and Management, 16(5), 980-994. https://doi.org/10.3846/16111699.2013.799087

Von Hippel, E. (1978). A customer active paradigm for industrial product idea generation. In M. J. Baker (Ed.). Industrial Innovation, 7 , 240-266. London: Palgrave Macmillan. https://doi.org/10.1007/978-1-349-03822-0_5

Wales, W. J. (2015). Entrepreneurial orientation: a review and synthesis of promising research directions. International Small Business Journal, 34(1), 3-15. https://doi.org/10.1177/0266242615613840

Zahra, S. A. (1986). A cannonical analysis of corporate entrepreneurship antecedents and impact on performance. Academy of Management Proceedings, 1, 71-75. https://doi.org/10.5465/ambpp.1986.4978718

Zahra, S. A. (1991). Predictors and financial outcomes of corporate entrepreneurship: an exploratory study. Journal of Business Venturing, 6(4), 259-285. https://doi.org/10.1016/0883-9026(91)90019-A

Ziman. (1991). A neural net model of innovation. Science and Public Policy, 18(I), 65-75. https://doi.org/10.1093/spp/18.1.65

Zortea-Johnston, E., Darroch, J., \& Matear, S. (2012). Business orientations and innovation in small and medium sized enterprises. International Entrepreneurship and Management Journal, 8(2), 145-164. https://doi.org/10.1007/s11365-011-0170-7 


\section{ENTREPRENEURSHIP AND SUSTAINABILITY ISSUES}

ISSN 2345-0282 (online) http://jssidoi.org/jesi/ 2021 Volume 9 Number 1 (September) http://doi.org/10.9770/jesi.2021.9.1(6)

Manuela ESCOBAR-SIERRA Professor of the doctorate in administration of the faculty of economic and administrative sciences at the University of Medellìn. Doctor in industry and organizations engineering, Master in administrative engineering and Industrial Engineering. ORCID ID: https://orcid.org/0000-0003-1865-6238

Felipe CALDERON-VALENCIA Professor of the law faculty at the University of Medellìn. Doctor in law, Magister comparative law, Master in history and Lawyer.

ORCID ID: $\underline{\text { https://orcid.org/0000-0001-7384-7470 }}$

Make your research more visible, join the Twitter account of ENTREPRENEURSHIP AND SUSTAINABILITY ISSUES: @Entrepr69728810

Copyright (C) 2021 by author(s) and VsI Entrepreneurship and Sustainability Center

This work is licensed under the Creative Commons Attribution International License (CC BY).

http://creativecommons.org/licenses/by/4.0/

(c) (†) Open Access 